\title{
WHO WERE THE LOTHARINGIANS? DEFINING POLITICAL COMMUNITY AFTER THE END OF THE CAROLINGIAN EMPIRE
}

\author{
Simon MacLean
}

\section{Introduction}

This article deals with ethnic labels and their uses in the political discourses of the post-Carolingian world. As a starting point, we can use one of the bestknown texts on notions of identity in tenth-century Europe, which comes in the middle of Bishop Liudprand of Cremona's vitriolic, self-serving, and entertaining account of his embassy to Constantinople in 968. Invited to dinner one evening, Liudprand was made to sit at a humiliating distance from his host, the Byzantine Emperor Nicephorus Phocas, and spent the meal enduring not only the appallingly oily food but also a series of insults directed towards his own patron, the king of East Francia and Italy — and emperor - Otto I. After a bout of aggressive banter about the gluttony and poor skills of the Ottonian army, Nicephorus finished with a rhetorical coup-de-grâce intended to belittle the very notion of a Western Empire, which had been recently revived by Otto after a gap of nearly half a century: 'You are not Romans, but Lombards!' At this Liudprand lost his composure, retorting that Romulus (the mythical founder of Rome) had been a fratricide and the son of a whore, and that the original Romans had been nothing more than debtors, slaves, and fugitive murderers. He continued:

We, that means the Lombards, Saxons, Franks, Lotharingians, Bavarians, Swabians and Burgundians, so disdain them that we utter no other insult than 'You Roman!' to our enemies when aroused, and we understand that single term, the name of

Simon MacLean is Professor of Medieval History, University of St Andrews.

Historiography and Identity IV: Writing History Across Medieval Eurasia, ed. by Walter Pohl and Daniel Mahoney, CELAma 30 (Turnhout: Brepols, 2021), pp. 247-274 
the Romans, to include every baseness, every cowardice, every kind of greed, every promiscuity, every mendacity, indeed every vice. ${ }^{1}$

The fact that Liudprand embraced rather than refuted Nicephorus's insult that he aggressively rejected the identification of Rome with imperial status rather than seeking to reclaim it - is striking because it seems to run contrary to mainstream definitions of political order in the early Middle Ages, which were customarily saturated in the imagery of Romanitas. ${ }^{2}$ Indeed, Otto I's own imperial coronation had been staged in Rome in February 962, as had that of his son Otto II at Christmas 967, only a few months before Liudprand took ship to Constantinople. Yet in drawing a contrast between the multiregnal diversity of the West and the avowedly uniform 'Roman-ness' of the Byzantine Empire and other Mediterranean polities, the bishop of Cremona was not completely alone. In 871, when the Byzantine Emperor Basil I belittled the imperial stature of the Carolingian ruler Louis II by pointing out that he was in territorial terms no more than a king of Italy, Louis's angry response included the observation that the kings of the other Western kingdoms were his relatives, and that the Frankish empire was thus constituted precisely by the sum of its parts. ${ }^{3} \mathrm{~A}$ similar comparison appears in the description of another Ottonian embassy, led by the monk John of Gorze, to the court of Caliph 'Abd ar-Rahman in Cordoba in the mid-950s. The author of John's Life puts into the caliph's mouth a speech criticizing Otto's habit of delegating power to representatives in different parts of his realms, and although the text breaks off before we hear the ambassador's comeback it is clear that the intention was to lampoon the oriental despotism of the Cordoban court by comparing its suffocating centralization with the common-sense devolution of the West. ${ }^{4}$ In the late ninth and tenth centuries, then, it was perfectly possible for Western apologists to celebrate the polycentrism of the Frankish/Saxon empire as a source of its strength rather than (as claimed by Nicephorus, Basil, 'Abd ar-Rahman, and even some modern historians) its key weakness. Beneath Liudprand's exaggerated version of his exchange with the emperor therefore lies a genuine contrast between the self-perceptions of the Frankish and Mediterranean worlds in the

${ }^{1}$ Liudprand, Legatio, ed. by Chiesa, 11-12, pp. 192-93; trans. by Squatriti, 11-12, pp. 246-47.

${ }^{2}$ Smith, Europe after Rome, pp. 253-92.

${ }^{3}$ Fanning, 'Imperial Diplomacy'. See also McKitterick, ed., Being Roman after Rome, themed issue of Early Medieval Europe.

${ }^{4}$ John of St-Arnulf, Vita Johannis Gorzie, ed. by Parisse, 136, pp. 160-61; Nelson, 'Rulers and Government', pp. 125-29. 
tenth century. His bold assertion that the natural units of political order were the sub-imperial gentes (peoples) represents a distinctively Western mindset.

One implication of this is that even though early medieval writers frequently referred to ethnic communities, and sometimes even provided abstract definitions of what they meant by the term 'gens', ethnic labels in the ninth and tenth centuries did not refer only, or even primarily, to ethnicity. ${ }^{5}$ Liudprand's list of peoples does not reflect a purely ethnographic sensibility, but uses 'national' labels to denote the elite political communities which in his view constituted Otto's kingdom. These labels carried political weight. ${ }^{6}$ As Tim Reuter aptly put it: 'Ethnicity appears to have lit up in the presence of rulers in much the same way as fluorescent clothing does in the presence of street lighting. ${ }^{7} \mathrm{On}$ top of this proxy role in political discourse, statements about ethnicity in early medieval sources could also be heavily informed by providential and legal discourses. ${ }^{8}$ Such statements do not, therefore, correlate directly to modern notions of national identity.

The consequent problem of whether and how we can move from discourse to identity has much occupied historians of the early Middle Ages. ${ }^{9}$ Yet the ambiguity of ethnic classification is also what makes it useful, as a tool which we can use to prise open the smooth surfaces of early medieval sources and access the imagined landscapes of contemporary politics. This article examines some of the key political dynamics of tenth century Europe via the history of the most enigmatic of Liudprand's 'peoples': the Lotharingians.

\section{Who Were the Lotharingians?}

The Lotharingians were unlike the other gentes in Liudprand's list in that they were a 'new' group. Indeed, Lotharingia is one of the great paradoxes of Frankish history. ${ }^{10}$ On the one hand, its story is one of fleeting existence and

5 On contemporary definitions see e.g. Goetz, 'Gens'; Pohl, 'Strategies of Identification'.

${ }^{6}$ On the use of ethnic terms to describe political communities see e.g. Goetz, 'Gentes'; Reuter, 'Whose Race'.

7 Reuter, 'Whose Race', pp. 103-04.

${ }^{8}$ Innes, 'Historical Writing'. On legal status and Frankishness see e.g. West, Reframing the Feudal Revolution, p. 24. On methodology see especially Bartlett, 'Medieval and Modern Concepts of Race and Ethnicity'; Reuter, 'Whose Race'; Pohl, 'Strategies of Identification'; Brubaker and Cooper, 'Beyond Identity'.

${ }^{9}$ For an overview of the 'ethnogenesis' debate see now Wood, The Modern Origins, pp. 299-329.

${ }^{10}$ For a recent introduction with further references see MacLean, 'Shadow Kingdom'. 
pronounced discontinuity. Its origins lay in the Treaty of Verdun of 843, which ended the wars between the sons of Louis the Pious (814-40) by dividing his empire into three kingdoms. Lothar I, the eldest son, received the middle kingdom stretching from the Low Countries to central Italy. What we usually refer to as Lotharingia was the northern part of this realm, inherited by (and ultimately named after) his like-named son in $855 .{ }^{11}$ But Lothar II's kingdom (lying roughly between the Rivers Scheldt and Meuse in the west and the Rhine in the east) was itself ephemeral. His turbulent reign was dominated by a controversial and highly political divorce case which divided and embarrassed his political elites, and when he died in 869 without legitimate heir the realm itself was split down the middle and absorbed into the kingdoms of his powerful uncles to either side. ${ }^{12}$ This was only the first of numerous divisions and reallocations - and although it was briefly revived in a different form for Lothar's cousin Zwentibald between 895 and 900, this was effectively the end of Lotharingia's history as an independent kingdom. ${ }^{13}$

On the other hand, the same story has also been told as a narrative of surprising continuity. Even setting aside the fact that a version of the region survives (via a long history of disputed claims and European wars) as the French administrative region of Lorraine, in the ninth and tenth centuries the concept of the kingdom seemingly persisted even when it did not formally exist. Thus after the death of Lothar II in 869 there are relatively frequent references to the 'regnum Lotharii' (Lothar's kingdom); and in the early tenth century we start to read of 'Lotharingians. ${ }^{14}$ From the 930 s, these Lotharingians were sometimes said to have had their own leaders called 'dukes'. And by the time we reach the proOttonian historians of the 960 s, the Lotharingians are explicitly referred to as a people ('gens') with specific characteristics. According to Widukind of Corvey they were 'a skilful people, accustomed to ingenuity, ready for war and adaptable to the outcome of events. ${ }^{15}$ Ruotger of Cologne describes the Lotharingians as having been a 'savage' people before they were tamed by Duke Bruno, the

Invaluable full-length studies are provided by Schneider, Auf der Suche, and West, Reframing the Feudal Revolution.

${ }^{11}$ See Parisot, Le royaume de Lorraine, pp. 747-53 on Lothar II as the eponymous figure.

12 On the divorce and its consequences see now Airlie, 'Unreal Kingdom'.

13 Schneider and Martine, 'La production d'un espace'.

${ }^{14}$ Bauer, Lotharingien, pp. 12-68.

15 Widukind of Corvey, Rerum gestarum Saxonicarum libri tres, ed. by Hirsch, I.30, pp. 42-43 ('quia gens varia erat et artibus assueta bellis prompta mobilisque ad rerum novitates'); II.15, pp. 79-80; II.36, pp. 95-97. 
brother of Otto I. ${ }^{16}$ And it was Liudprand of Cremona, a contemporary of these writers, who was first to use the abstract term 'Lotharingia' to refer to a particular territory. ${ }^{17} \mathrm{Of}$ all the spectral lost kingdoms and subkingdoms into which the Frankish empire was periodically divided, this one was exceptional in witnessing the planting and evolution of a new community label. Why might this have been? What can this apparent example of a people and a kingdom becoming identified with a king, rather than the more common reverse, tell us about politics and ethnic discourse in the late ninth and early tenth centuries? ${ }^{18}$

These questions have a truly enormous historiography, but the recent debate is quite polarized. Some have argued that the evolution of the terminology (regnum - people - territory) reflects the ever-increasing solidity of Lotharingian identity, hot-housed by regional resistance to interference from the larger kingdoms on either side. ${ }^{19}$ Others have deconstructed the idea of Lotharingian-ness as a genuinely felt identity, underlining the absence of evidence for the kinds of phenomenon from which group identities would normally derive, such as shared histories, persistent cultural bonds, and a consistent sense of geography. ${ }^{20}$ The near-absence of clear statements of Lotharingian identity in Lotharingian sources is a telling element in this argument: although attributions of territorial and group labels are fairly consistent in the century after Lothar II's death, it is unavoidably the case that they come overwhelmingly from the perspectives of outsiders writing in West Francia, Saxony, and Italy.

Nonetheless, it is widely accepted that ethnicity is a relational and situational concept - a manipulable category rather than an inert witness to fundamental beliefs and identities. ${ }^{21}$ This means that even classifications imposed by outsiders should be taken seriously - self-identifications and external labels are linked, and discussions of social and ethnic identity need to take account

${ }^{16}$ Ruotger of Cologne, Vita Brunonis, ed. by Schmale-Ott, 39, pp. 41-42.

${ }^{17}$ Liudprand, Antapodosis, ed. by Chiesa, II.18, p. 43; II.25, p. 46 and Historia, ed. by Chiesa, 14, p. 177; 22, p. 182. On Liudprand's words for territories and peoples see Gandino, Il vocabolario, pp. 237-80.

18 The peculiarity was underlined by Reuter, 'Whose Race', p. 106 (and for parallels see Schneider, Auf der Suche, pp. 261, 442). For a sophisticated exploration of such questions in the case of tenth-century Saxony, see Becher, Rex, dux und gens.

19 Anton, 'Synoden'; Bauer, Lotharingien.

${ }^{20}$ Schneider, Auf der Suche; Margue, “'Nous ne sommes ni de l'une, ni de l'autre”, published in Gaillard and others, eds, De la mer du nord. The latter volume contains a representative variety of opinions.

${ }^{21}$ Geary, 'Ethnic Identity as a Situational Construct'. 
of the dialectic between them. ${ }^{22}$ With this in mind, the intention of the present article is not to take sides in the debate over the existence or otherwise of Lotharingian identity, far less to resolve it. Rather, I will defer the question of whether or not the language of our sources reflects genuine identity and solidarity, and ask instead how and why authors of the earlier tenth century might have chosen to use certain terms and expressions. Specifically, my enquiry is limited to explicit references to 'the Lotharingians' as a group, a term used habitually by modern historians to refer to elites of the middle kingdom from the 850s onwards, but rarely if ever found in sources written before c. 920 . This terminology should be taken seriously because while we may be unsure about whether successive deployments of this concept denote the existence of a continuous and conscious group, we can at minimum read them as rhetorical attempts to assert the existence of such a group. After all, the terminology of our sources never simply reflects social reality, but also helps construct it. My argument is that early coinings of the term 'Lotharingians' make most sense as strategic manoeuvres within the fluid context of a specifically post-Carolingian politics - and can therefore be used in turn to illuminate a world in which established definitions of political order were coming unstuck, and new ones were competing to take their place. ${ }^{23}$

One indication of the shift from Carolingian to post-Carolingian is the very absence of new historical narratives written in the wake of the empire's disintegration in 888 . The relatively abundant supply of ninth-century narratives dries up shortly thereafter, with no long-form contemporary histories written in East Francia, northern Italy, or the middle kingdom between Regino of Prüm's Chronicle (908) and the revival of the 960s represented by the work of Liudprand and Widukind. In West Francia, an equivalent silence is broken only by Flodoard of Reims, whose Annals and History are invaluable, but limited by their close focus on Reims and its environs. The annalistic tradition of the eighth and ninth centuries was firmly anchored in Carolingian political order, structured around patterns of royal movement and the cycle of the religious calendar. ${ }^{24}$ After the end of the Carolingian monopoly on royal power, and especially after 900, ninth-century political patterns fractured as would-be

22 Jenkins, Social Identity, pp. 20-28; Jenkins, Rethinking Ethnicity, pp. 53-56; Pohl, 'Strategies of Identification', pp. 12-27. Cf. Brubaker and Cooper, 'Beyond Identity'.

23 Throughout this article I use 'post-Carolingian' in a limited and specific sense, to mean the period after the end of the Carolingian monopoly on royal power in the Frankish realms. For more on this definition see Airlie, Power and its Problems; MacLean, 'Carolingian Past'.

${ }^{24}$ McKitterick, History and Memory. 
kings in all parts of the Frankish world competed to establish their families (or re-establish them, in the case of the Carolingians themselves) as royal dynasties. As part of this competition, rulers were regularly deposed and crowns seldom passed from fathers to sons. That this period of uncertainty should have coincided with a break in the production of historical narrative is no accident the break itself might indicate a lack of confidence in the location and stability of the political centre, akin to a less dramatic version of the 'crisis of representation' which characterized the late and post-Roman world. ${ }^{25}$

Traces of this rupture might also be detected in the quasi-ethnic terminology used to describe political organization in the period. Ninth-century definitions of political order had orbited around a hegemonic notion of Frankishness as an umbrella political identity and as an emblem of elite membership. ${ }^{26}$ As the notion of a coherent Frankish empire became increasingly unsustainable after 888 , so too did the labels used to characterize its inhabitants: Frankishness became a more descriptive and precise term reserved for the inhabitants of Francia 'proper' (the West Frankish heartlands and Franconia); while older classical terms also found new purchase. ${ }^{27}$ Ethnic qualifiers in royal titulature (title plus people) had also been integral to ninth-century idioms of political authority, with Carolingian rulers often represented as 'kings of the Franks' and variations thereof. The first Ottonian kings, by contrast, were normally announced simply as 'king', perhaps reflecting a wariness of adopting Carolingian styles too ostentatiously while descendants of Charles the Bald still aspired to rule west of the Rhine (though contemporary narratives do sometimes style them in 'Frankish' terms).$^{28}$ Likewise, while the Ottonians did allow some nobles the title 'dux' (or duke), they were extremely reluctant to enrich this with an ethnic qualifier. The most powerful of the Lotharingian dukes in the earlier tenth century, Giselbert, is only called 'dux of the Lotharingians' in one royal charter. ${ }^{29} \mathrm{It}$ is no coincidence that this comes from the first months of the reign of Otto I, who was at this point (and by means of this charter) seeking to cement a relationship with Giselbert and to assert his claim to regard Lotharingia as part

${ }^{25}$ Heydemann, 'Biblical Israel'.

26 See McKitterick, History and Memory; Innes, 'Historical Writing', pp. 544-47; Koziol, The Politics of Memory and Identity, p. 225; Reimitz, 'The Providential Past', pp. 109-35.

27 Schneidmüller, 'Adso von Montier-en-Der'; Brühl, Deutschland - Frankreich, pp. 83-180; cf. Pohl, 'Gens ipsa peribit'.

${ }^{28}$ Brühl, Deutschland - Frankreich, pp. 163-69. On the significance of the 'of the Franks'style formulation, see Pohl, 'Christian and Barbarian Identities', esp. pp. 12-15.

${ }^{29}$ Die Urkunden Otto I., ed. by Sickel, no. 6, pp. 94-95. 
of his kingdom in the face of a genuine challenge from his Carolingian rival Louis IV. In other words, the qualifying term 'of the Lotharingians' here is not neutral and is as significant as the title 'dux' - it represents a public concession to Giselbert, made in peculiar circumstances. There is thus meaning, and deliberation, in formal uses of this quasi-ethnic terminology in tenth-century political discourse. ${ }^{30}$

This, then, is the context in which we should evaluate our sources' earliest references to a group known as 'the Lotharingians', who are curious in the first instance because they are not 'the Franks'. What connotations might this coinage have had in the first decades of the tenth century? How might its deployment have made sense in an unstable political situation which the powerful sought to control by asserting their own visions of community? And how might we take this story across the chasm which separates the 'regnum Lotharii' of the late ninth century from the world of Widukind of Corvey and Liudprand of Cremona, in which for the first time Lotharingia had become a territory and the Lotharingians a people?

\section{The Emergence of 'the Lotharingians'}

The first explicit appearance of 'the Lotharingians' is in the two versions of the so-called Alemannic Annals, surviving in manuscripts from Zurich and Monza but probably written in the monastery of St-Gall, near Lake Constance, around $920 .{ }^{31}$ It is certainly reasonable to regard the collective noun as having evolved from the later ninth-century concept of the 'regnum Lotharii' - but even if so, the timing and context of the shift requires further examination. On closer inspection, one of the striking things about the sources written in the twenty years after 888 is the relative rarity of the expression 'regnum Lotharii' - all the more noticeable in that this includes a period (895-900) in which Lotharingia was a distinct kingdom with its own ruler (Zwentibald). The kingdom was never referred to as 'Lothar's' in the royal charters of Zwentibald, nor those of his father, the East Frankish king and emperor Arnulf (888-99); and it was hardly exclusive in the various narrative sources from the 890s. Contemporaries preferred a variety of terms (including 'Zwentibald's kingdom'; 'the Gallican kingdom'; 'province of the Western Franks'), which seems to highlight the absence of any settled designation in this period; and there are

${ }^{30}$ On the political weight carried by charter formulas see e.g. Keller, 'Zu den Siegeln'; Koziol, Politics of Memory. The classic study is Wolfram, ed., Intitulatio II.

31 Annales Alamannici, ed. by Lendi. 
no uses of 'Lothar's kingdom' in the decade after $895 .{ }^{32}$ In this light, perhaps we should hesitate before assuming the ubiquity and continuity of the concept of 'Lothar's kingdom', whose inhabitants were ready to emerge as full-fledged 'Lotharingians'.

This observation can be supported with evidence from the reign of the next East Frankish king Louis IV (900-11), Arnulf's other son who succeeded both his father and his brother after their respective deaths. Louis was born in 893, hence his nickname 'the Child' and his pressing need for experienced counsellors. The royal styles and images deployed by those counsellors in his charters and seals were intended to support pointed statements defending his authority and legitimacy. One of his charters, issued in 903 in favour of St-Gall, refers to the presence of the king's leading men, including a certain Gebhard 'duke of the kingdom which is called by many Lothar's [kingdom]. ${ }^{33}$ This passage has played a part in the long-running debate about the emergence of duchies in the postCarolingian period, and on its basis Gebhard has often been described as the first duke of Lotharingia. ${ }^{34}$ But - setting aside the fraught issue of ducal status - why is the reference to Gebhard's sphere of influence so awkwardly worded? Why not simply 'duke of Lothar's kingdom'? One explanation might be the very fact alluded to above, namely that the appellation 'Lothar's kingdom', which we tend to assume was commonplace after the 860 s, was in fact non-standard at the beginning of the tenth century. The term was apparently unfamiliar to the author of this charter, who presented it as something of a neologism.

This coinage could well have served a political end in the reign of Louis the Child, whose advisers were eager to disassociate him from his late half-brother Zwentibald because of the infamy of the latter's conduct. The reign had also ended murkily with the death of Zwentibald, who was possibly murdered and possibly by a faction sympathetic to Louis. ${ }^{35}$ Zwentibald was effectively erased from history in the official discourse of Louis's court: the simple fact that he had reigned is acknowledged only twice in Louis's charters, and in one

32 Annales Fuldenses, ed. by Kurze, a. 891, p. 119 and a. 895, p. 126 (Lothar's kingdom), a. 893, p. 122 (province of the Western Franks), a. 900, p. 134 (Gallican kingdom); Annales Vedastini, ed. by Simson, a. 879, p. 45; a.884, p. 55; a. 885, p. 56, a. 895, p. 75 (Lothar's kingdom), a. 896, p. 78; a. 898, p. 80 (Zwentibald's kingdom).

33 Die Urkunden Ludwigs des Kindes, ed. by Schieffer, no. 20, p. 126 ('dux regni quod a multis Lotharii dicitur').

${ }^{34}$ On this debate see Becher, Rex, dux und gens. I have learned much from two unpublished PhD theses: Hope, 'The Political Development'; Robbie, 'The Emergence of Regional Polities'.

35 Hartmann, 'Lotharingien in Arnolfs Reich', pp. 122-42. 
of those only to remind its audience that he had been deposed by 'the leading men (proceres) of Lothar's kingdom. ${ }^{36}$ Regino of Prüm, writing in 908 for the attention of one of Louis the Child's most influential courtiers and thus perhaps for the king himself, subscribed to this view, depicting Zwentibald as a disaster and consistently describing the kingdom he had ruled as the 'regnum Lotharii. ${ }^{37}$ This consistency was new, and stands in stark contrast to the varied terminology of the immediately preceding period. In view of all this, my suggestion is that the term 'Lothar's kingdom' was used in the court discourse of Louis the Child's reign as part of the black-ops campaign against the reputation of his predecessor - a conscious and pointed alternative to previously current terms like 'Zwentibald's kingdom'.

Another feature of the tentative re-emergence of this Lotharian association under Louis the Child is that all three of the royal charters which use the label 'regnum Lotharii' do so to refer not just to a territory, but also to an elite group - the 'proceres' of the 'regnum'. Furthermore, all three documents position the same figure as the leader of that alleged community: Duke (sometimes count) Gebhard. ${ }^{38}$ Gebhard was a member of a family, known to historians as the 'Conradines', which became powerful under Louis the Child, and in the first decade of the tenth century he was in the process of being forcibly installed as the king's representative in the middle kingdom. ${ }^{39}$ Any attempt to represent Gebhard's authority as legitimate in the midst of this very turbulent situation required that he be positioned as leader of what purported to be a regnal political community - regardless of whether such a community genuinely existed, and of whether he was actually able to exercise that authority. With this in mind it may be significant that Regino's Chronicle, written around the same time and directed towards Louis the Child's court circle, is also anxious to legitimize the blossoming power of the Conradines. Indeed, it finishes with the family triumphing over their enemies with the help of 'an army from Lothar's kingdom' - another image of collective allegiance. ${ }^{40}$

${ }^{36}$ Die Urkunden Ludwigs des Kindes, ed. by Schieffer, no. 57, p. 184, no. 70, p. 266 - the quote is from the latter (proceres regni Lothariensis).

${ }^{37}$ Regino of Prüm, Chronicle, ed. by Kurze, though NB Regino claimed the Lothar in question was Lothar I rather than his scandalous son.

38 Die Urkunden Ludwigs des Kindes, ed. by Schieffer, no. 20, p. 126; no. 55, p. 182; no. 70, p. 206.

${ }^{39}$ Hope, 'Political Development', pp. 221-26 points out that the charter proclaiming Gebhard's ducal status was issued during one of the military actions designed to do just that.

${ }^{40}$ Regino, Chronicle, ed. by Kurze, a. 906, pp. 150-53. For this interpretation of the end of Regino's work see MacLean, 'Insinuation'. 
Both the association of the middle kingdom with Lothar and the image of a coherent political community in that kingdom therefore make sense within the specific circumstances of Louis the Child's reign. This context can help us make sense of the explicit references to 'the Lotharingians' in the Alemannic Annals. Both versions of the text are sympathetic to the Conradine family, and particularly to the East Frankish ruler Conrad I (911-18), Gebhard's nephew, who had worked hard to establish links with the monastery of St-Gall, whence came not only the annals but also the charter which had described Gebhard as 'dux.' ${ }^{41}$ But it is also worth noting that both versions of the text first use the term in relation to the events of 911, when Gebhard and Louis the Child both died and the West Frankish king Charles the Simple annexed the middle kingdom. According to the version of the annals found in a Monza manuscript, 'the leaders of the Lotharingians (Hlothariorum principes) separated from King Louis' and 'the Lotharingians (Hlodarii) made Charles into king of Gaul (rex Galliae) over them'. Meanwhile, the version found in a Zurich manuscript describes Conrad I's struggles against Charles the Simple 'among the Lotharingians (in Hlodarios)' and his attempts to master 'the Franks who are called Lotharingians (Hlutharingi). ${ }^{42}$ As is well known, Charles ostentatiously proclaimed his acquisition of the middle kingdom in 911 as ideologically significant, defining it publicly as the moment at which he came into his full Carolingian inheritance - it is only from this point that his charters begin to describe him in nostalgic terms as 'king of the Franks'. His rule over 'the Franks', his control of Lotharingia, and his Carolingian heritage were here compressed into a single concept. ${ }^{43}$ At the time of the annals' composition, the beginning of the 920s, the Frankishness of 'Lotharingia' was pointedly reasserted by Charles at the Treaty of Bonn, and the matter of the middle kingdom was becoming a serious point of tension between Charles and the new East Frankish king Henry I (and between Charles and his own leading men). ${ }^{44}$ In a context like

${ }^{41}$ On Conrad and St-Gall, see Annales Alamannici, ed. by Lendi, a. 912, p. 188; Postel, 'Nobiscum partiri'.

42 Annales Alamannici, ed. by Lendi, a. 911, p. 188. The Zurich text also refers to the 'regnum Hlutharingorum' (realm of the Lotharingians) in 913. The variety of vocabulary here, even within a single text, may also betray the unusualness of the terminology.

43 Schneider, Auf der Suche, p. 120.

${ }^{44}$ For the Treaty of Bonn (at which Charles and Henry recognized each other as Frankish kings - but met on the Rhine, thus pointedly confirming the former's control of the middle kingdom), see Constitutiones et acta publica, ed. by Weiland, no. 1, pp. 1-2. For the tension over Lotharingia in Charles's reign see Depreux, 'Le comte Haganon'. 
this, language is charged with extra meaning. Those whom Charles defined emphatically as Franks, the annalists saw as 'Lotharingians', or at least 'Franks called Lotharingians'. This terminology can be read as a distancing strategy, a way of diluting the prized Frankishness that underwrote Charles's claims to the middle kingdom and aligning that regnum instead with East Frankish and/or Conradine definitions of political geography.

My suggestion is therefore that the concept of a regnal group of 'Lotharingians' originated amidst a cluster of competing assertions generated by the post -888 breakdown of Carolingian political geography and the associated contest for territory and legitimacy. We can tease out another hint of this dynamic from the only other early narrative source which deploys the new term 'Lotharingians': the Annals of Flodoard of Reims..$^{45}$ This is our only continuous narrative history of the West Frankish kingdom from the first half of the tenth century and runs from 919 to 966. It was written broadly contemporaneously, though it was probably not begun until about 922. West Frankish sources of this period often sought implicitly to deny the Frankish identity of the eastern kingdom and to claim that concept as a western monopoly. ${ }^{46}$ If the wording of the Alemannic Annals isolated 'the Lotharingians' from an idea of Frankishness which in West Francia was held to carry overtones of political legitimacy and Carolingian continuity, it can be argued that the opening few entries of Flodoard's Annals reflect an opposing perspective. In 919, for example, Flodoard explicitly describes the 'regnum Lotharii' as 'part of Francia.. ${ }^{47}$ This established, he then makes frequent references to 'the Lotharingians' as actors on the political stage. Theirs was an area with which Flodoard was intimately familiar: Reims had important lands in the middle kingdom, and its eastern-facing interests help explain why his other work, a history of the church of Reims written c. 950, was dedicated to Archbishop Robert of Trier.

But despite Flodoard's regular and generally neutral use of the term to mean the elites of the middle kingdom, his vocabulary becomes more finegrained when he gets into the detail of the factional conflicts in and over Lotharingia in the 920s and 930s. His depiction of Giselbert, by far the most powerful figure in the regnum in this period, is particularly ambiguous. In his entry for 923, the annalist recounts how Giselbert turned against the West Frankish king Raoul and invited the eastern ruler Henry I to invade - in Flodoard's telling, it is only those who were then loyal to Raoul, led by Count

\footnotetext{
45 On Flodoard see now Roberts, 'Flodoard'.

46 Schneidmüller, 'Adso von Montier-en-Der'.

${ }^{47}$ Flodoard, Annales, ed. by Lauer, a. 919, p. 1.
} 
Otto of Verdun, who are referred to as 'Lotharingians. ${ }^{48}$ Later, when Giselbert and Otto together made peace with Raoul, there is an implication that in Flodoard's eyes 'the Lotharingians' whom they brought with them were specifically associated with Otto rather than with Giselbert. ${ }^{49}$ And when Flodoard then says that 'all the Lotharingians' switched back to Henry I, the context suggests again that he is referring primarily to the southern group around Otto of Verdun. ${ }^{50}$ In fact, Flodoard's entries in the 920 s can be read with surprising regularity as implicitly associating the label 'Lotharingians' with groups in the south, around Metz and Verdun. ${ }^{51}$ In the 930s, Flodoard's distaste for Giselbert seems to have diminished (partly because of Giselbert's supporting role in West Frankish politics) and he is now associated in the Annals with the 'Lotharingians' and even recognized as 'dux', as were to be his successors in that role, Otto of Verdun and Conrad the Red. When Flodoard focuses more closely on Lotharingian affairs in his description of the troubles faced by the latter in the early 950s, however, he again draws some implicit distinctions, for example between the 'Lotharingians' whose towers Conrad had demolished and the 'Verdun-ers' who were deprived of offices. ${ }^{52}$ In 959, he uses the general term 'Lotharingians' for the faction which followed Count Immo in rejecting a new Ottonian duke. ${ }^{53}$

Flodoard's infamously terse prose means that even his more straightforward comments often need to be parsed and decoded, so it is very difficult to identify consistent patterns in his Annals. Nor can we expect this text to

48 Flodoard, Annales, ed. by Lauer, a. 923, p. 18.

${ }^{49}$ Flodoard, Annales, ed. by Lauer, a. 925, p. 29 says that Raoul came to Cambrai to meet 'Lothariensibus atque Gisleberto' (the Lotharingians as well as Giselbert); but that 'they' (apparently meaning 'the Lotharingians') did not turn up and instead met him on the Meuse, where Giselbert and Otto made peace with him.

${ }^{50}$ Flodoard, Annales, ed. by Lauer, a. 925, p. 33. In the same passage Flodoard describes Henry effecting a change of bishop in Verdun. Giselbert's followers are implicitly distinguished by virtue of being described merely as 'his fideles'.

${ }^{51}$ Flodoard, Annales, ed. by Lauer, a. 926, pp. 35-36 refers to a conflict in Verdun as a struggle of the 'Lotharienses among themselves'. In 928, pp. 42-43, he describes Count Boso's attempts to take bites out of Giselbert's powerbase in the north and the properties of the churches of Verdun and Metz in the south, and refers to the peace subsequently brokered by Henry I as between 'Giselbert [on the one hand] and the other Lotharingians [on the other]' (the brackets indicate my reading of Flodoard's compressed text).

${ }^{52}$ Flodoard, Annales, ed. by Lauer, a. 951, pp. 130-31: the terms used are 'Lotharienses' and 'Virdunensii'.

53 Flodoard, Annales, ed. by Lauer, a. 959, p. 146. 
articulate a coherent political position - Flodoard wrote continuously and in the midst of perpetually changing circumstances, so his perspective was not static. This seems to apply even to his use of such an apparently neutral term as 'the Lotharingians', by which he does not always refer to the political community of the middle kingdom as a whole, nor to any single group within that community. Sometimes at least Flodoard deploys the label to ascribe or deny legitimacy to specific actors at moments when the politics of the middle kingdom came under his microscope. But even if the thinking behind his vocabulary choices remains ultimately opaque, Flodoard's fine distinctions do underline the instability of such terminology, especially at moments of tension. In a world where political geography was commonly defined using quasi-ethnic categories, such terms were not merely descriptive - their deployment could carry overtones which defined some groups and not others as representing the essence of a region's political community. ${ }^{54}$

The ideological weight carried by such terms becomes much greater when they appear in the formal titulature of charters. These were highly stylized texts by means of which rulers of all kinds not only enacted legal transactions, but also refined their self-image and projected it to elite audiences in very precise ways. As mentioned above, one of the striking features of Ottonian royal charters is their drafters' reluctance to use ethnic qualifiers to enhance the titles of kings or dukes. The charter from 903 in which Gebhard was called duke of 'Lothar's kingdom' and the 936 document in which Giselbert is named 'duke of the Lotharingians' are exceptional, and as argued earlier can be explained with reference to the unusual circumstances in which they were composed and issued. Of forty charters, royal and non-royal, in which a 'dux' is mentioned in the middle kingdom between 903 and 959, the 936 document is in fact the only one to clearly supply 'of the Lotharingians' as an ethnic qualifier. ${ }^{55}$

${ }^{54}$ Cf. Annales Augienses, ed. by Pertz, a. 939, p. 69, where we find a report of Otto I attacking the 'Lutheringos', the term again surfacing in the context of a rebellion (as did the text itself, which was apparently composed for Archbishop William of Mainz at the end of the second Lotharingian rebellion of 953-54).

55 This is based on the invaluable table compiled by Schneider, Auf der Suche, pp. 127-28 (with his analysis at pp. 124-48). I omit examples of territorial qualifiers: one charter from a monastery in Giselbert's heartland refers to him as 'duke of Lothar's kingdom' in 934; and two documents from 949 and 951/52 refer to Conrad as 'duke of the Lotharingian kingdom' and 'duke of Lothar's kingdom' respectively. Schneider (p. 126 n. 509) excludes as forgeries Die Urkunden Otto I., ed. by Sickel, no. 70, pp. 150-51, no. 140, pp. 220-21, no. 169, p. 251 and no. 179 , pp. 261-62, none of which contains an ethnic qualifier (though no. 70 was issued on the intervention of 'Cuonradi Lodariensis ducis' (Conrad the Lotharingian duke)). 
From the few years after 959, though, we have an unusual group of charters which offer us a glimpse of a duke who styled himself in much grander terms, and who also provides us with the first clear evidence of a Lotharingian identifying him or herself as such: Frederick I. Frederick was count of Bar in the southern part of Lotharingia and belonged to a family whose members dominated the region for much of the later tenth and eleventh centuries - they are known to historians (perhaps misleadingly) as 'the Ardenner. ${ }^{56} \mathrm{He}$ was very well connected in the south, and especially around Metz and Verdun: he was (probably) the step-brother of Otto of Verdun, and (definitely) the brother of the powerful bishop Adalbero I of Metz (929-64). ${ }^{57}$ It was presumably on the back of these family connections that Frederick was named 'dux' in the southern part of Lotharingia in 959 by Archbishop Bruno of Cologne, the brother of Otto I to whom ducal oversight of the region had been delegated. ${ }^{58}$ Despite his family credentials, Frederick's rise carried the whiff of new money because he seems not to have been a major landowner in the area. What properties he did have came via his marriage to Beatrice, a daughter of the West Frankish duke Hugh 'the Great' of Tours who carved out her dower from the southern Lotharingian holdings of the Parisian monastery of St-Denis. ${ }^{59}$ Beatrice's mother Hadwig, moreover, was a sister of Otto I and Bruno of Cologne. Frederick's status, then, derived from family, institutions, and offices more than from land per se control of monasteries and the parading of titles were more important to his rise than the accumulation of property.

This is the context for a series of three documents in which Frederick was identified as 'dux' in remarkably exalted terms. The first, composed in 959 at the monastery of Gorze, which had close links to Metz, describes a dispute over land in which Frederick, brokering a compromise, is described as 'duke by the grace of God and election of the Franks. ${ }^{60}$ The second, dated 8 September 962, describes how Frederick gave a ruling on the correct ownership of a particular group of properties at an assembly in the cemetery of the monastery of St-Mihiel. He is referred to as 'duke of the Lotharingians by the compassionate grace of God,

56 Margue, 'Structures de parenté.

57 Parisse, 'Généalogie de la Maison d'Ardenne'.

${ }^{58}$ For interesting (but not widely accepted) arguments against Bruno's formal division of Lotharingia into northern and southern 'duchies' in 959, see Barth, Der Herzog in Lotharingien, pp. 130-67.

59 Parisse, 'Saint-Denis'; Parisse, 'Bar au XI siècle'; Parisse, 'In media Francia.'

${ }^{60}$ Cartulaire de l'abbaye de Gorze, ed. by D’Herbomez, no. 108, p. 198 ('gratia Dei et electione Francorum dux'). 
and lord of the monks of St-Mihiel and the community of that institution', and is depicted pompously addressing himself to 'the princes and noble men of my duchy. ${ }^{61}$ The third (966) records a dispute involving the abbey of Bouxières-auxDames, a few miles east of Toul, in which Frederick ('duke of the Lotharingians by the grace of God') pronounced in favour of the institution. ${ }^{62}$

How are we to understand the use of such titles for Frederick, which are unprecedented even from the era of Giselbert, who was a considerably more powerful duke? One solution has been to suggest that the documents are forgeries, or at least that they were touched up between their composition and their insertion into the cartularies where we now find them. There are indeed some peculiarities, particularly in the titles used in the Gorze charter, but numerous details provided by the texts are verifiable, and even the most sceptical commentators have been unwilling to dismiss the St-Mihiel and Bouxières documents. ${ }^{63}$ The unusual terminology becomes more comprehensible if we take into account the communities which produced these texts and constituted their primary audiences. St-Mihiel on the Meuse was the key institution controlled by Frederick and Beatrice, who had received it as part of her dower at the time of her betrothal in 951 or marriage in 954 - this was the headquarters of their 'rule'. Indeed, a series of kings had competed for influence there at the end of the ninth century, indicating that it was regarded as critical for the exercise of political authority in the region. ${ }^{64}$ Bouxières, by contrast, was a recent aristocratic foundation notionally in the control of the bishop of Toul, but Frederick seems to have had ambitions to dominate it: his (successful) attempt to insert himself as the presiding authority in the 966 dispute was an assertion of lordship, perhaps akin to a takeover bid. ${ }^{65}$ Something similar may have been going on at Gorze, whose protection and patronage was regarded by the community (on the evidence of a text written in the monastery in the 980s)

${ }^{61}$ Chronique et chartes, ed. by Lesort, no. 27, p. 120 ('F. Dei miserante gratia dux Lothariensium et senior monachorum sancti Michaelis et familiae ejusdem potestatis').

${ }^{62}$ Les origines de l'abbaye de Bouxières-aux-Dames, ed. by Bautier, no. 33, p. 112 ('F. divina comitante gratia Lothariensium dux').

63 The key discussion of the charters is Parisse, 'Les possessions', pp. 243-47. Schneider, Auf der Suche, pp. 265-66 raises doubts about the charters' authenticity based primarily on their titulature.

${ }^{64}$ Parisse, 'In media Francia', pp. 331-37.

${ }^{65}$ Nightingale, Monasteries, pp. 157-58, 165-66. For conflict between Frederick's family and Bishop Gerard of Toul, see Parisse, 'In media Francia'; and on the latter see also Nightingale, 'Bishop Gerard of Toul'. 
as a ducal prerogative. ${ }^{66}$ Given that Frederick's regional position relied on his control of such institutions and on his ability to make good his claims to ducal status, his aggressive advertising of that status to audiences at these communities makes sense - not as a straightforward snapshot of his actual role but as a shrill attempt to strengthen his probably insecure grasp on authority in what he and Beatrice claimed as their sphere of influence.

The declaration in two of these charters that Frederick was duke 'of the Lotharingians' can be seen as part of this legitimating strategy, but also points us towards a broader context. Frederick's elevation in 959 to the status of 'dux' (whatever exactly that meant) and his assertion of leadership over 'the Lotharingians' coincided with a broader political reorientation in the region. This involved an apparent division of the region into northern and southern 'duchies', and was prompted by the exile of the powerful northern Lotharingian magnate Reginar III in 957-58. ${ }^{67}$ Reginar was Giselbert's nephew, and his exile and dispossession appeared to signify the termination of a family line which had enjoyed pre-eminent status in the region's aristocratic community for several generations. The West Frankish rulers then took the unprecedented step of formally renouncing their claims to the middle kingdom in 959, and the Ottonian court moved to reassert its interests in the region, symbolized by a special coronation for Otto II at Aachen in 961 'with the agreement of all the Lotharingians' - a striking representation of the latter as a semi-autonomous political community. ${ }^{68}$ These events inaugurated a period of rapid repositioning among local elites, exemplified by the repeated side-switching of a faction led by Count Immo. ${ }^{69}$ Now, for the first time, the eastern kings were in a position to really make good their claims to rule Lotharingia — and in early 966 , Otto I himself took a direct interest for the first time in many years, making a rare personal visit during which he 'arranged all the affairs of the Lotharingian kingdom as he deemed suitable.70

${ }^{66}$ Miracula sancti Gorgonii, ed. by Goullet and others, 20-22, pp. 188-95. Beatrice was commemorated as a ruler (ductrix) at Gorze: Le Jan, Famille et pouvoir, p. 37. Her absence from the three documents under discussion may be because they are judgements rather than grants.

${ }^{67}$ Flodoard, Annales, ed. by Lauer, a. 957, p. 144; Adalbert, Continuatio, ed. by Kurze, a. 958, p. 169; MacLean, Ottonian Queenship, pp. 76-86.

${ }^{68}$ Flodoard, Annales, ed. by Lauer, a. 959, p. 146; Adalbert, Continuatio, ed. by Kurze, a. 961, p. 171.

${ }^{69}$ Dierkens, 'Un membre de l'aristocratie lotharingienne'.

${ }^{70}$ Adalbert, Continuatio, ed. by Kurze, a. 966, p. 177. The death of Bruno of Cologne in 965 was another reason for this visit. 
As it turned out, none of these events was definitive: Reginar's children would soon be back to stake their claims, West Frankish ambitions were rekindled, and the Ottonians consequently struggled to assert themselves definitively in the area at least until 987 and probably well beyond. Nonetheless, they indicate that our documents' grandiose declarations about Frederick's position were formulated at a particular political moment which made such claims more accessible to the new duke's apologists. Proclaiming leadership of a community of 'Lotharingians' in the context of intensifying Ottonian interest was an opportunistic way of universalizing Frederick's claims to legitimate authority in the middle kingdom as he sought to convert limited resources into a secure powerbase and to orchestrate aggressive expansionary moves.

The moment passed. Frederick's career becomes less clear thereafter, and his successors are shadowy figures even allowing for the patchiness of the evidence. ${ }^{71}$ Nonetheless, we may catch a distant echo of these dynamics in the eleventh-century Chronicle of St-Mibiel, which in some ways serves as a history of Beatrice and Frederick's family through their association with the monastery. This tells the story of how the duke built his fortress at Bar on the frontier between Lotharingia and Champagne, implicitly placing the border some twenty-five kilometres west of the Meuse; while sources from Toul located it on the Meuse itself, as did Flodoard, who dropped his habitual inscrutability and complained in his Annals that Frederick's activity was an encroachment upon the territory of 'this kingdom.' ${ }^{72}$ For the author of the Chronicle, therefore, the westward expansion of Frederick's interests constituted the westward expansion of Lotharingia - in effect, Frederick and his family were the Lotharingians.

It is possible, then, to understand Frederick's titulature as a form of opportunism linked to his ambitions in the region of Lotharingia around St-Mihiel and Toul. But this evidence is not completely isolated, for we have a hint that Frederick's self-perception was echoed in the political discourse of the royal court. This comes in the shape of a royal charter from June 960 which describes Otto I in highly irregular terms as 'king of the Lotharingians, Franks and Germans. ${ }^{73}$ Primarily on the basis of this unique titulature, the text has often

${ }^{71}$ Parisse, 'Les possessions', pp. 247-51; Parisse, 'Les hommes'.

72 Chronique et chartes, ed. by Lesort, 7, pp. 11-12; Flodoard, Annales, ed. by Lauer, a. 951, p. 130; Parisse, 'In media Francia', pp. 327-28. On the frontier in general see Bur, 'La frontière', pp. 241-42; Parisse, 'La frontière de la Meuse'.

73 Die Urkunden Otto I., ed. by Sickel, no. 210, p. 298 ('Otto divina providente clementia rex Lothariensium Francorum atque Germanensium') (one or other of the terms could be read as adjectival, but the general point stands). 
been dismissed as a forgery, even though the surviving version appears to be a contemporary document with verifiable historical content. ${ }^{74}$ But the naming of Duke Frederick and his brother Bishop Adalbero of Metz as the people who requested the grant, and the fact that it was issued for - and probably drawn up by - a monastic community under their influence, St-Pierre in Metz, make it plausible that it was a genuine product of the same political context as the documents from St-Mihiel and Bouxières. ${ }^{75}$

Even if the document was composed by and reflected the perspective of the recipients, this does not mean that its perspective was purely 'private. The concept of a 'royal chancery' staffed by dedicated notaries policing a strictly defined body of formulas seems much less secure today than it once did, with historians now willing to imagine 'official' documents as products of collaboration and communication between the royal entourage and external scriptoria, often including the beneficiaries of the charters themselves. ${ }^{76}$ Despite its unusual titulature, the charter for St-Pierre contains almost all of the hallmarks of style and presentation that we expect from authentic royal diplomas of this period - application of Ockham's Razor would therefore suggest that the document could indeed have been official, whatever we customarily mean by that. That being the case, we have here a sign of convergence between the local and royal discourses describing the political community which Frederick claimed to lead. ${ }^{77}$

This observation gives us a bridge back to our starting point: the world of the Ottonian historians of the 960s, and in particular Widukind of Corvey, who was the first author to describe the Lotharingians as a people (gens) with specific attributes. We can hardly call Widukind's Deeds of the Saxons an official history - he was not even a courtier - but it was written towards the court: the dedicatee was Otto's daughter Mathilda, and the text was certainly informed by the political disputes and discourses of the $960 \mathrm{~s}^{78} \mathrm{With}$ this in mind, it should be emphasized that Widukind's novel description of the Lotharingians was not written as a passing comment, but forms part of a coherent and argumentative narrative in book I of his work, which deals with the disintegration of the Carolingian world and its re-coagulation in the hands of the

${ }^{74}$ Parisse, 'Les faux diplômes ottoniens', p. 582.

75 Cf. Wolfram, 'Lateinische Herrschertitel', pp. 133-37.

76 See e.g. Koziol, Politics of Memory, pp. 32, 56-57.

${ }^{77}$ NB the reform of Gorze by Frederick's brother Adalbero was recorded in a charter dated to the reign of Henry I in regno Lothariorum: Cartulaire de l'abbaye de Gorze, ed. by D’Herbomez, no. 92, p. 173.

78 Robbie, 'Can Silence Speak Volumes'. 
first Ottonian king Henry I. A series of legendary stories set in the deep past establishes the transfer of power from the Franks to the Saxons, and Widukind then describes the achievements of Henry himself as a sequence of victories over powerful figures cast as leaders of 'ethnic' political communities: Eberhard representing the Franks, Arnulf representing the Bavarians, and Burchard the Alemans. ${ }^{79}$ He then turns to the middle kingdom, offering a potted history which culminates in Henry's collaboration with the cunning Lotharingians to capture Giselbert and gain his submission..$^{80}$ Widukind's story of Henry I's rise is, therefore, a story about his progressive acquisition of power over a series of regions characterized as gentes led by dukes. ${ }^{81}$ Such a view of the structures of Saxon power demanded that the Lotharingians be regarded as a gens.

This way of describing the Ottonian kingdom was characteristic of the high point of the reign of Otto ('rex gentium') in the 960s, and coincided with the reemergence of long-form historical narratives ${ }^{82}$ If the absence of such texts after Regino of Prüm put down his pen in 908 represented a reaction to the dynastic instability of the period amounting to a crisis of representation, then their reappearance around 960 can be linked to the dawning Ottonianization of the post-Carolingian world. With the coronation of Otto II as king in 961 (and as emperor in 967), for the first time in sixty years a post-Carolingian throne passed directly to the third generation of a ruling dynasty. For sympathizers like Widukind and Liudprand, the 'crisis' was over. These authors had no problem in confidently describing the way the world was put together and were certain about the location of its political centre. This is why Liudprand's list of Otto's peoples ('Lombards, Saxons, Franks, Lotharingians, Bavarians, Swabians, and Burgundians') was not only a negative rhetorical attempt to devalue Byzantine notions of Romanness - it also points towards a more positive definition of Western political order. Later in his invective against Nicephorus, Liudprand went a step further, referring to 'our people (gens nostra), namely, all those who are under [Otto's] rule. ${ }^{83}$ For the bishop of Cremona, what bound these groups

79 Widukind, Rerum gestarum Saxonicarum libri tres, ed. by Hirsch, I.23-27, pp. 35-40.

${ }^{80}$ Widukind, Rerum gestarum Saxonicarum libri tres, ed. by Hirsch, I.28-30, pp. 40-43.

${ }^{81}$ Widukind's other explicit references to the Lotharingians as a gens are also connected to their place in Ottonian structures of authority: Rerum gestarum Saxonicarum libri tres, ed. by Hirsch, II.15, pp. 79-80 (Otto visits them after a victory), II.36, pp. 95-97 (Bruno of Cologne is established as their duke).

82 Goetz, 'Gentes', pp. 108-10; Beumann, 'Imperator Romanorum, rex gentium'.

${ }^{83}$ Liudprand, Legatio, ed. by Chiesa, 40, p. 204 ('nostram nunc dico omnem, quae sub vestro imperio est, gentem'). 
into a people was not the perpetuation of a Frankish past, not some kind of replacement pan-Saxonness, and certainly not the concept of Rome, but the Ottonian dynasty itself. For Liudprand and like-minded apologists for the new order, the Lotharingians were not simply one of the peoples that made up the Ottonian kingdom - they were 'a people' because they were a constituent part of the Ottonian kingdom. ${ }^{84}$

\section{Conclusion}

If the crystallization of the idea of the Lotharingians as a gentile community was an aspect of the hardening idioms used to define the Ottonian Reich, this helps explain why this terminology, previously so patchy, becomes more common and less ambiguous from the 960s onwards. Still, the language of Lotharingianness hardly became ubiquitous, even in the eleventh century. ${ }^{85}$ Where we have evidence, self-identification of people in the middle kingdom as Frankish remained common, and Frankishness remained an important element in definitions of royal power well beyond the period discussed in this article. ${ }^{86}$ As will be clear, the vocabulary of Lotharingian group belonging was far from consistent, never mind transparent; and the evidence itself is extremely patchy and requires a lot of detailed analysis to fit it into a broader historical picture. Moreover, we have only looked at explicit references to the Lotharingians as a group, which represents only a sliver of the evidence underlying the many major studies on this subject. Conclusions reached on this basis can hardly be definitive.

But even if the sources do not allow us into the hearts of the people described, they can, surely, tell us something about the minds of those doing the describing. By considering the sources precisely as isolated snapshots rather than as links in a continuous chain we catch a flavour of the political anxieties of the earlier tenth century. The variety of the vocabulary in this context attests to the malleability of the underlying concepts, and the various uses to which they could be put in what Robert Bartlett has described as the 'fertile confusion of post-Carolingian Europe. ${ }^{87}$ The end of the empire intensified an intermittent

${ }^{84}$ There may also have been an attempt here to claim for Otto the leadership of all the Christian people, in the sense of Cassiodorus's commentary on Psalms (as cited by Heydemann, 'Biblical Israel', p. 180): '[The Psalmist's] mention of a gens in the singular indicates the Christian people (populus); for though we are instructed that it is gathered from many gentes, they are rightly called a single gens, for they are known to be sprung from the one origin of baptism.

85 Bauer, Lotharingien, pp. 30-43; Margue, 'De la Lotharingie à la Lorraine'.

${ }^{86}$ Schneider, Auf der Suche, pp. 258-73.

${ }^{87}$ Bartlett, The Making of Europe, p. 311. 
debate over political geography in which ethnic labels could act as proxies for claims to authority in traditional Carolingian idioms - but in a world where the gravitational pull of Frankishness was weakening. As traditional reference points lost some of their hegemony, competing visions of community variously served to legitimize and delegitimize, to strategically distinguish, and to universalize the status claims of regional factions. The concept of Frankishness by no means vanished, but its authority was diluted as different groups and authors improvised new variations on the theme - new identifications rather than new identities - to describe and shape a rapidly changing world. ${ }^{88}$ This was perhaps most evident in contested regions like Lotharingia, whose precarious 'in-betweenness' gave rise to the specific conditions discussed above.

Viewed in this perspective, it would be difficult to argue that the persistence of 'gentile' terminology is evidence for persistent community feeling. But at the same time there is a danger in reducing the evidence to 'mere' discourse, because discourse is also part of social reality. That classification itself is an important means by which social realities (including ethnic identities) are constituted is well appreciated by modern scholars, but was apparently understood even by Regino of Prüm, who wrote in his mini-ethnography of the Hungarians that they must have been a new people because in the past they were 'never named'. 89 Names, once institutionalized, can themselves become reference points for self-identifications. ${ }^{90}$ To put this another way, we should not assume that kingdoms are creations of communities and their attendant identities - in fact the reverse is frequently the case. ${ }^{91}$ The hardening of Ottonian political structures must have played a part in institutionalizing the idioms and practices amidst which the concept of a Lotharingian community began to take shape. That being the case, perhaps the true starting point for a history of that community should be located in the 960 s rather than the 860 s. $^{92}$

88 On the advantages of 'identification' over 'identity' as an analytical concept, see Brubaker and Cooper, 'Beyond Identity'; Pohl, 'Strategies of Identification'. On the post-Carolingian period as a time of frantic political improvisation see Airlie, 'The Nearly Men'.

${ }^{89}$ Regino, Chronicle, ed. by Kurze, a. 889, p. 131.

${ }^{90}$ Jenkins, Social Identity, pp. 126-38.

${ }^{91}$ Brubaker and Rogers, 'Beyond Identity', pp. 25-28. This is of course a chicken/egg problem: Pohl, 'Strategies of Identification', pp. 44-48.

92 This is also the implication of the arguments presented by Schneider, Auf der Suche. For valuable feedback I am grateful to Stuart Airlie, Marios Costambeys, Jinty Nelson, Jens Schneider, and Charles West. This article forms part of the HERA JRP III project 'After Empire: Using and Not Using the Past in the Crisis of the Carolingian Empire'. 


\section{Works Cited}

\section{Primary Sources}

Annales Alamannici, ed. by Walter Lendi, in Untersuchungenzurfrühalemannischen Annalistik: Die Murbacher Annalen, mit Edition (Freiburg: Universitätsverlag, 1971), pp. 146-92

Annales Augienses, ed. by Georg Heinrich Pertz, in Monumenta Germaniae Historica: Scriptores, 1 (Hanover: Hahn, 1826), pp. 67-69

Annales Fuldenses, ed. by Friedrich Kurze, Monumenta Germaniae Historica: Scriptores rerum Germaniae in usum scholarum, 7 (Hanover: Hahn, 1891)

Annales Vedastini, ed. by Bernhard Simson, Monumenta Germaniae Historica: Scriptores rerum Germaniae in usum scholarum, 12 (Hanover: Hahn, 1909)

Cartulaire de l'abbaye de Gorze, ed. by Armand d'Herbomez (Paris: Klincksieck, 1898)

Chronique et chartes de l'abbaye de Saint-Mihiel, ed. by André Lesort (Paris: Klincksieck, 1909-12)

Constitutiones et acta publica imperatorum et regum inde ab anno DCCCXI usque ad annum MCXCVII (911-1197), ed. by Ludwig Weiland, Monumenta Germaniae Historica: Leges constitutiones, 1 (Hanover: Hahn, 1893)

Flodoard of Reims, Annales, in Les Annales de Flodoard, ed. by Philippe Lauer (Paris: Picard, 1906)

John of St-Arnulf, Vita Johannis Gorzie, in La vie de Jean, abbé de Gorze, ed. by Michael Parisse (Paris: Picard, 1999)

Liudprand of Cremona, Antapodosis, ed. by Paolo Chiesa, in Liudprandi Cremonensis opera omnia, Corpus christianorum, continuatio mediaevalis, 156 (Turnhout: Brepols, 1998), pp. 1-150; trans. by Paolo Squatriti, in The Complete Works of Liudprand of Cremona (Washington, DC: Catholic University of America Press, 2007), pp. 41-220

— , Historia Ottonis, ed. by Paolo Chiesa, in Liudprandi Cremonensis opera omnia, Corpus christianorum, continuatio mediaevalis, 156 (Turnhout: Brepols, 1998), pp. 167-83; trans. by Paolo Squatriti, in The Complete Works of Liudprand of Cremona (Washington, DC: Catholic University of America Press, 2007), pp. 219-37

- Relatio de legatione Constantinopolitana, ed. by Paolo Chiesa, in Liudprandi Cremonensis opera omnia, Corpus christianorum, continuatio mediaevalis, 156 (Turnhout: Brepols, 1998), pp. 185-218; trans. by Paolo Squatriti, in The Complete Works of Liudprand of Cremona (Washington, DC: Catholic University of America Press, 2007), pp. 232-82

Miracula sancti Gorgonii, in Sources hagiographiques de l'histoire de Gorze, ed. by Monique Goullet, Michel Parisse, and Anne Wagner (Paris: Picard, 2010), pp. 152-203

Les origines de l'abbaye de Bouxières-aux-Dames au diocèse de Toul: reconstitution du chartrier et édition critique des chartes antérieures à 1200, ed. by Robert Henri Bautier (Nancy: Société d'archéologie Lorraine, 1987)

Regino of Prüm, Chronicle, ed. by Friedrich Kurze, Reginonis abbatis Prumiensis chronicon, cum continuatione Treverensi, Monumenta Germaniae Historica: Scriptores rerum Germaniae in usum scholarum, 50 (Hanover: Hahn, 1890) 
Ruotger of Cologne, Vita Brunonis, ed. by Irene Schmale-Ott, Monumenta Germaniae Historica: Scriptores rerum Germanicarum nova series, 10 (Weimar: Böhlau, 1951)

Die Urkunden Konrad I., Heinrich I. und Otto I., ed. by Theodor Sickel, Monumenta Germaniae Historica: Diplomata regum et imperatorem Germaniae, 1 (Hanover: Hahn, 1879-84)

Die Urkunden Zwentibolds und Ludwigs des Kindes, ed. by Theodor Schieffer, Monumenta Germaniae Historica: Diplomata regum Germaniae ex stirpe Karolinorum, 4 (Berlin: Weidmann, 1960)

Widukind of Corvey, Rerum gestarum Saxonicarum libri tres, ed. by Paul Hirsch, Monumenta Germaniae Historica: Scriptores rerum Germanicarum separatim editi, 60 (Hanover: Hahn, 1935)

\section{Secondary Studies}

Airlie, Stuart, 'Unreal Kingdom: Francia Media under the Shadow of Lothar II', in De la mer du Nord à la Méditerranée: Francia Media, une région au cour de l'Europe (c. 840-c. 1050), ed. by Michèle Gaillard and others (Luxembourg: Publications du CLUDEM, 2011), pp. 339-56

_- 'The Nearly Men: Boso of Vienne and Arnulf of Bavaria', in Stuart Airlie, Power and its Problems in the Carolingian Empire, Variorum Collected Studies, 1010 (Farnham: Ashgate, 2012), Item XI, pp. 1-19

- , Power and its Problems in the Carolingian Empire, Variorum Collected Studies, 1010 (Farnham: Ashgate, 2012)

Anton, Hans Hubert, 'Synoden, Teilreichsepiskopat und die Herausbildung Lotharingiens (859-70)', in Herrschaft, Kirche, Kultur: Beiträge zur Geschichte des Mittelalters; Festschrift für Friedrich Prinz, ed. by Georg Jenal (Stuttgart: Hiersemann, 1993), pp. 83-124

Barth, Rüdiger, Der Herzog in Lotharingien im 10. Jahrhundert (Sigmaringen: Thorbecke, 1990)

Bartlett, Robert, The Making of Europe: Conquest, Colonization and Cultural Change, 950-1350 (London: Penguin, 1993)

- , 'Medieval and Modern Concepts of Race and Ethnicity', Journal of Medieval and Early Modern Studies, 31 (2001), 39-56

Bauer, Thomas, Lotharingien als historischer Raum: Raumbildung und Raumbewusstsein im Mittelalter (Cologne: Böhlau, 1997)

Becher, Matthias, Rex, dux und gens: Untersuchungen zur Entstehung des sächsischen Herzogtums im 9. und 10. Jahrhundert (Husum: Matthiesen, 1996)

Beumann, Helmut, 'Imperator Romanorum, rex gentium: Zu Widukind III 76', in Helmut Beumann, Ausgewählte Aufsätze aus den Jahren 1966-1986 (Sigmaringen: Thorbecke, 1987), pp. 324-40

Brubaker, Rogers, and Frederick Cooper, 'Beyond Identity', Theory and Society, 29 (2000), 1-47

Brühl, Carlrichard, Deutschland - Frankreich: Die Geburt zweier Völker (Cologne: Böhlau, 1995) 
Bur, Michel, 'La frontière entre la Champagne et la Lorraine du milieu du $\mathrm{X}^{\mathrm{e}}$ à la fin du $\mathrm{XII}^{\mathrm{e}}$ siècle', Francia, 4 (1976), 237-54

Depreux, Philippe, 'Le comte Haganon, favori de Charles le Simple, et l'aristocratie entre Loire et Rhin', in De la mer du Nord à la Méditerranée: Francia Media, une région au cour de l'Europe (c. 840-c. 1050), ed. by Michèle Gaillard and others (Luxembourg: Publications du CLUDEM, 2011), pp. 381-93

Dierkens, Alain, 'Un membre de l'aristocratie lotharingienne au $\mathrm{X}^{\mathrm{e}}$ siècle: le comte Immon', Bulletin de l'Institut archéologique liégeois, 100 (1988), 21-32

Fanning, Steven, 'Imperial Diplomacy between Francia and Byzantium: The Letter of Louis II to Basil I in 871', Cithara, 34 (1994), 3-15

Gaillard, Michèle, and others, eds, De la mer du Nord à la Méditerranée: Francia Media, une région au cour de l'Europe (c. 840-c. 1050) (Luxembourg: Publications du CLUDEM, 2011)

Gandino, Germana, Il vocabolario politico e sociale de Liutprando di Cremona (Rome: Istituto storico italiano per il medio evo, 1995)

Geary, Patrick, 'Ethnic Identity as a Situational Construct in the Early Middle Ages', Mitteilungen der anthropologischen Gesellschaft in Wien, 113 (1983), 15-26

Goetz, Hans Werner, 'Gentes: Zur zeitgenössischen Terminologie und Wahrnehmung ostfränkischer Ethnogenese im 9. Jahrhundert', Mitteilungen des Instituts für österreichische Geschichtsforschung, 108 (2000), 85-116

__, 'Gens: Terminology and Perception of the "Germanic" Peoples from Late Antiquity to the Early Middle Ages', in The Construction of Communities in the Early Middle Ages, ed. by Richard Corradini, Maximilian Diesenberger, and Helmut Reimitz (Leiden: Brill, 2003), pp. 39-64

Hartmann, Martina, 'Lotharingien in Arnolfs Reich: das Königtum Zwentibolds', in Kaiser Arnolf: Das ostfränkische Reich am Ende des 9. Jahrbunderts, ed. by Franz Fuchs and Peter Schmid (Munich: Beck, 2002), pp. 122-42

Heydemann, Gerda, 'Biblical Israel and the Christian gentes: Social Metaphors and the Language of Identity in Cassiodorus's Expositio Palmarum', in Strategies of Identification: Ethnicity and Religion in Early Medieval Europe, ed. by Walter Pohl and Gerda Heydemann (Turnhout: Brepols, 2013), pp. 143-208

Hope, George, 'The Political Development of the Carolingian Kingdom of Lotharingia, 870-925' (unpublished doctoral thesis, University of Glasgow, 2006)

Innes, Matthew, 'Historical Writing, Ethnicity and National Identity: Medieval Europe and Byzantium in Comparison', in The Oxford History of Historical Writing, II: 400-1400, ed. by Sarah Foot and Chase F. Robinson (Oxford: Oxford University Press, 2012), pp. 539-74

Jenkins, Richard, Social Identity (London: Routledge, 1996)

- Rethinking Ethnicity: Arguments and Explorations (London: SAGE, 1997)

Keller, Hagen, 'Zu den Siegeln der Karolinger und der Ottonen: Urkunden als "Hoheitszeichen" in der Kommunikation des Königs mit seinem Getreuen', Frühmittelalterliche Studien, 32 (1998), 400-41

Koziol, Geoffrey, The Politics of Memory and Identity in Carolingian Royal Diplomas: The West Frankish Kingdom (840-987) (Turnhout: Brepols, 2012) 
Le Jan, Régine, Famille et pouvoir dans le monde franc (VII $-X^{e}$ siècle): essai d'anthropologie sociale (Paris: Publications de la Sorbonne, 1995)

MacLean, Simon, 'Insinuation, Censorship and the Struggle for Late Carolingian Lotharingia in Regino of Prüm's Chronicle', English Historical Review, 124 (2009), 1-28

— 'Shadow Kingdom: Lotharingia and the Frankish World, c. 850-c. 1050', History Compass, 11 (2013), 443-57

—, 'The Carolingian Past in Post-Carolingian Europe', in The Making of Europe: Essays in Honour of Robert Bartlett, ed. by John Hudson and Sally Crumplin (Leiden: Brill, 2016), pp. 11-29

—, Ottonian Queenship (Oxford: Oxford University Press, 2017)

Margue, Michel, 'De la Lotharingie à la Lorraine: les pouvoirs en Lorraine dans la deuxième moitié du XI ${ }^{\mathrm{e}}$ siècle', in Léon IX et son temps, ed. by Georges Bischoff and BenoîtMichel Tock (Turnhout: Brepols, 2006), pp. 471-94

_- " “Nous ne sommes ni de l'une, ni de l'autre, mais les deux à la fois”: Entre France et Germanie, les identités lotharingiennes en question(s)', in De la mer du Nord à la Méditerranée: Francia Media, une région au coeur de l'Europe (c. 840-c. 1050), ed. by Michèle Gaillard and others (Luxembourg: Publications du CLUDEM, 2011), pp. 395-427

— , 'Structures de parenté et processus d'identification dans la Lotharingie des $\mathrm{X}^{\mathrm{e}}$ et $\mathrm{XI}^{\mathrm{e}}$ siècles: le cas du groupement familial dit "d'Ardenne", in Splendor reginae: passions, genre et famille; mélanges en l'honneur de Régine Le Jan, ed. by Laurent Jégou and others (Turnhout: Brepols, 2015), pp. 79-92

McKitterick, Rosamond, History and Memory in the Carolingian World (Cambridge: Cambridge University Press, 2004)

—, ed., Being Roman after Rome, Themed Issue: Early Medieval Europe, 22 (2014)

Nelson, Janet L., 'Rulers and Government', in The New Cambridge Medieval History, III: c. 900-1024, ed. by Timothy Reuter (Cambridge: Cambridge University Press, 1999), pp. 95-129

Nightingale, John, 'Bishop Gerard of Toul (963-94) and Attitudes to Episcopal Office', in Warriors and Churchmen in the High Middle Ages: Essays Presented to Karl Leyser, ed. by Timothy Reuter (London: Hambledon, 1992), pp. 41-62

-, Monasteries and Patrons in the Gorze Reform: Lotharingia, c. 850-1000 (Oxford: Oxford University Press, 2001)

Parisot, Robert, Le royaume de Lorraine sous les carolingiens (843-923) (Paris: Picard, 1898)

Parisse, Michel, 'Saint-Denis et ses biens en Lorraine et en Alsace', Bulletin philologique et historique, 1 (1967), 233-56

—_, 'Bar au XI ${ }^{\mathrm{e}}$ siècle: la comtesse Sophie et les origines de la ville', in Bar-le-Duc: journées d'études Meusiennes (Nancy: Université de Nancy II, 1976), pp. 5-28

—_, 'Généalogie de la Maison d'Ardenne', in La Maison d'Ardenne, $X^{e}-X I^{e}$ siècle, Publications de la section historique de l'Institut G.-D. de Luxembourg, 95 (Luxembourg: Beffort, 1981), pp. 9-41

_ - 'Les possessions des ducs de Haute-Lotharingie (959-1033)', in La Maison d'Ardenne, $X^{e}-X I^{e}$ siècle, Publications de la section historique de l'Institut G.-D. de Luxembourg (Luxembourg: Beffort, 1981), pp. 241-57 
— , 'In media Francia: Saint-Mihiel, Salonnes et Saint-Denis (VII ${ }^{\mathrm{e}}-\mathrm{XII}{ }^{\mathrm{e}}$ siècles)', in Media in Francia: recueil de mélanges offert à Karl Ferdinand Werner (Paris: Hérault, 1989), pp. 319-43

—_, 'La frontière de la Meuse au $\mathrm{X}^{\mathrm{e}}$ siècle', in Haut moyen âge: culture, éducation et société; études offertes à Pierre Riché, ed. by Michel Sot (Nanterre: Publidix et éditions européennes Erasme, 1990), pp. 427-37

- 'Les hommes et le pouvoir dans la Lorraine de l'an mil', in Religion et culture autour l'an mil: Royaume capétien et Lotharingie, ed. by Dominique Iogna-Prat and JeanClaude Picard (Paris: Picard, 1990), pp. 259-66

_ _ 'Les faux diplômes ottoniens pour la Lorraine: essai de critique horizontale', in Vielfalt und Aktualität des Mittelalters: Festschrift für Wolfgang Petke zum 65. Geburtstag, ed. by Sabine Arend (Bielefeld: Verlag für Regionalgeschichte, 2007), pp. 575-89

Pohl, Walter, 'Gens ipsa peribit: Kingdom and Identity after the End of Lombard Rule', in 774: ipotesi su una transizione, ed. by Stefano Gasparri (Turnhout: Brepols, 2008), pp. $67-78$

- 'Christian and Barbarian Identities in the Early Medieval West', in Post-Roman Transitions: Christian and Barbarian Identities in the Early Medieval West, ed. by Walter Pohl and Gerda Heydemann (Turnhout: Brepols, 2013), pp. 1-46

—, 'Strategies of Identification: A Methodological Profile', in Strategies of Identification: Ethnicity and Religion in Early Medieval Europe, ed. by Walter Pohl and Gerda Heydemann (Turnhout: Brepols, 2013), pp. 1-64

Postel, Verena, 'Nobiscum partiri: Konrad I. und seine politischen Berater', in Konrad I.: Auf dem Weg zum 'Deutschen Reich'?, ed. by Hans-Werner Goetz (Bochum: Winkler, 2006), pp. 129-49

Reimitz, Helmut, 'The Providential Past: Visions of Frankish Identity in the Early Medieval History of Gregory of Tours' Historiae (Sixth-Ninth Century)', in Visions of Community in the Post-Roman World: The West, Byzantium and the Islamic World, 300-1100, ed. by Walter Pohl, Clemens Gantner, and Richard Payne (Farnham: Ashgate, 2012), pp. 109-35

Reuter, Timothy, 'Whose Race, Whose Ethnicity? Recent Medievalists' Discussions of Identity', in Timothy Reuter, Medieval Polities and Modern Mentalities, ed. by Janet L. Nelson (Cambridge: Cambridge University Press, 2006), pp. 100-08

Robbie, Steven, 'Can Silence Speak Volumes? Widukind's Res gestae Saxonicae and the Coronation of Otto I Reconsidered', Early Medieval Europe, 20 (2012), 333-62

_ , 'The Emergence of Regional Polities in Burgundy and Alemannia, c. 888-940: A Comparative Assessment' (unpublished doctoral thesis, University of St Andrews, 2012)

Roberts, Edward, 'Flodoard, the Will of St Remigius and the See of Reims in the Tenth Century', Early Medieval Europe, 22 (2014), 201-30

Schneider, Jens, Auf der Suche nach dem verlorenen Reich: Lotharingien im 9. und 10. Jahrhundert (Cologne: Böhlau, 2010)

Schneider, Jens, and Tristan Martine, 'La production d'un espace: débuts lotharingiens et pratiques de la frontière', Revue de géographie historique, 4 (2014) <http://rgh. univ-lorraine.fr/articles/view/43/La_production_d_un_espace_debuts_lotharingiens_et_pratiques_de_la_frontiere_IXe_XIe_siecle> [accessed 12 September 2017] 
Schneidmüller, Bernd, 'Adso von Montier-en-Der und die Frankenkönige', Trierer Zeitschrift für Geschichte und Kunst des Trierer Landes und seiner Nachbargebiete, 40/41 (1977/78), 189-99

Smith, Julia M. H., Europe after Rome: A New Cultural History, 500-1000 (Oxford: Oxford University Press, 2005)

West, Charles, Reframing the Feudal Revolution: Political and Social Transformation between Marne and Moselle, c. 800-c. 1100 (Cambridge: Cambridge University Press, 2013)

Wolfram, Herwig, ed., Intitulatio, II: Lateinische Herrscher- und Fürstentitel im neunten und zehnten Jahrbundert (Vienna: Böhlau, 1973)

— - 'Lateinische Herrschertitel im neunten und zehnten Jahrhundert', in Intitulatio, II: Lateinische Herrscher- und Fürstentitel im neunten und zehnten Jahrhundert, ed. by Herwig Wolfram (Vienna: Böhlau, 1973), pp. 19-178

Wood, Ian, The Modern Origins of the Early Middle Ages (Oxford: Oxford University Press, 2013) 